\title{
TESTING THE LIMITS OF ACADEMIG FREEDOM
}

The Supreme Court has long identified academic freedom as "a special concern of the First Amendment." 1 Almost all the cases in which claims of academic freedom have arisen, however, have involved the first amendment rights of individual teachers. ${ }^{2}$ Although at least one Justice has suggested that academic freedom is an institutional as well as an individual right, ${ }^{3}$ the Court has not yet issued such a holding.

A recent case, Princeton University v. Schmid, ${ }^{4}$ raised the question whether private universities enjoy special protection under the first amendment. Although the Court found it unnecessary to decide that question in this case, ${ }^{\mathbb{5}}$ the issue remains a significant one for private universities seeking to challenge governmental regulation.

Schmid was perhaps not the best vehicle to resolve this issue. The case concerned the arrest and conviction for trespassing of a nonstudent who distributed leaflets on Princeton's campus. The New Jersey Supreme Court overturned the conviction, holding that the state constitution protected an outsider's right to speak on Princeton's property. ${ }^{6}$ The court interpreted the state constitution as a guarantee of free speech rights "not only against governmental or public bodies, but under some circumstances against private per-

1 Keyishian v. Board of Regents, 385 U.S. 589, 603 (1967); see Barenblatt v. United States, 360 U.S. 109, 112 (1959); Sweezy v. New Hampshire, 354 U.S. 234, 250 (1957).

2 See, e.g., Keyishian v. Board of Regents, 385 U.S. 589 (1967) (invalidating New York's teacher loyalty oath); Barenblatt v. United States, 360 U.S. 109 (1959) (upholding conviction of former professor who refused to answer questions on Communist Party membership posed by House Committee on Un-American Activities); Sweezy v. New Hampshire, 354 U.S. 234 (1957) (reversing contempt conviction of a professor who refused to answer state inquiry about content of lecture at state university); Wieman v. Updegraff, 344 U.S. 183 (1952) (invalidating loyalty oath required of faculty members at state college).

3 See Regents of the Univ. of Cal. v. Bakke, 438 U.S. 265, 312 (1978) (opinion of Powell, J., announcing the judgment of the Court) (suggesting that academic freedom includes the freedom of a university to make its own educational decisions); see also Sweezy v. New Hampshire, 354 U.S. 234, 263 (1957) (opinion of Frankfurter, J., concurring in the result) (citing a statement of a conference of South African scholars that emphasized " the four essential freedoms' of a university-to determine for itself on academic grounds who may teach, what may be taught, how it shall be taught, and who may be admitted to study.").

450 U.S.L.W. 4159 (U.S. Jan. 12, 1982) (No. 80-1576), dismissing appeal from State v. Schmid, 84 N.J. 535, 423 A.2d 615 (1980).

5 See infra note 9 and accompanying text.

B State v. Schmid, 84 N.J. 535, 569, 423 A.2d 615, 633 (1980). 
sons as well." 7 The court held that when property has been opened to public use, as has Princeton's campus, ${ }^{8}$ its owner may not unreasonably regulate the distribution of leaflets or other expressive activity by strangers. ${ }^{9}$

At first glance, the case appeared to pit individual free speech rights against property rights. Princeton, however, considered the New Jersey decision an unconstitutional intrusion by the state into a university's educational decisionmaking. ${ }^{10}$ Princeton contended that the first amendment guarantees academic freedom to institutions as well as to individuals. In Princeton's view, this institutional right of academic freedom includes a university's right to choose its "educational atmosphere." 11 Maintenance of the desired atmosphere, Princeton argued, requires control over the university campus, ${ }^{12}$ which is "devoted to expressive purposes." ${ }^{13}$ The decision to restrict expressive activity on campus is therefore an educational decision, protected by the first amendment. In short, Princeton considered property rights in this case "almost incidental" to first amendment rights. ${ }^{14}$

A university's assertion of a right to exclude ideas from its campus in the name of academic freedom may seem paradoxical; a university is traditionally thought of as the marketplace of ideas,

7 Id. at $559,423 \mathrm{~A} .2 \mathrm{~d}$ at 628.

$8 \mathrm{Id}$. at $564-65,423 \mathrm{A.2d}$ at 631.

9 Id. at 567-68, 423 A.2d at 632-33. "[W] hile the case was pending on appeal [to the New Jersey Supreme Court], the University substantially amended its regulations governing solicitation, distribution of literature, and similar activities on University property by those not affiliated with the University." 50 U.S.L.W. at 4160 . The U.S. Supreme Court, therefore, labeled the validity of the old regulation a moot issue. Id. It dismissed the appeal for want of jurisdiction, holding that Princeton lacked standing and noting that "the presence of the State of New Jersey in [the] case [did] not provide a sound jurisdictional basis for undertaking to decide difficult constitutional issues." Id.

The Court did not discuss the issue of state action. State action sufficient to raise a constitutional claim, however, may not have occurred. The state action that Princeton challenged was actually state inaction: the state's refusal to enforce its trespass laws. See Brief of Appellee Chris Schmid at 15-18, Princeton Univ. v. Schmid, 50 U.S.L.W. 4159 (U.S. Jan. 12, 1982) (No. 80-1576) [hereinafter cited as Schmid Brief].

${ }^{10}$ See Brief of Appellant Princeton University at 6-8, Princeton Univ. v. Schmid, 50 U.S.L.W. 4159 (U.S. Jan. 12, 1982) (No. 80-1576) [hereinafter cited as Princeton Brief]; Prepared text for argument in the Supreme Court of New Jersey by Nicholas deB. Katzenbach on behalf of The Trustees of Princeton University (Intervenor) in State v. Schmid, 84 N.J. 535, 423 A.2d 615 (1980), at 5 [hereinafter cited as Prepared Text].

11 Princeton Brief, supra note 9 , at 11 .

12 Id. 13.

13 Id. 6.

14 Prepared Text, supra note 10, at 5. 
open to all. This apparent contradiction, however, should not cloud the underlying issues. Princeton's contention that academic freedom extends to institutions as well as to individuals is far from frivolous. After a brief review of Schmid in part I, this Comment in part II argues that the core educational functions of universities should indeed enjoy special protection under the first amendment.

Princeton's argument faltered, however, in its linkage of academic freedom to the facts of Schmid. Part III contends that the first amendment protection Princeton claimed does not extend to the university's decision to restrict arbitrarily the distribution of leaflets on its campus. Nevertheless, part III concludes that the New Jersey decision was incorrect because of its unnecessary reliance on the content of the university's educational philosophy. ${ }^{15}$

Leaving aside the problem of content neutrality, part IV suggests that other constitutional arguments support Princeton's position. Part IV concludes, however, that under a recent Supreme Court decision, PruneYard Shopping Center v. Robins, ${ }^{16}$ these arguments are not sufficient to prevent the state from regulating expressive activity on university property. Finally, part V suggests that although the states are not constitutionally required to treat university campuses differently from shopping centers, certain policy considerations may incline them to do so.

\section{State Constitutions and Federal Rights}

On April 5, 1978, Chris Schmid, a member of the United States Labor Party (U.S.L.P.), was distributing and selling political materials on the campus of Princeton University. ${ }^{17}$ Neither Schmid

1584 N.J. at 564-65, 423 A.2d at 631; cf. Police Dep't of Chicago v. Mosely, 408 U.S. 92, 95 (1972) ("[A]bove all else, the First Amendment means that government has no power to restrict expression because of its message, its ideas, its subject matter, or its content.").

16447 U.S. 74 ( 1980 ).

1784 N.J. at 538, 423 A.2d at 616. Schmid's materials dealt with the candidacy of a U.S.L.P. member in the Newark mayoral campaign and described the U.S.L.P. in general. Jurisdictional Statement at $49 \mathrm{a}$, Princeton University v. Schmid, 50 U.S.L.W. 4159 (U.S. Jan. 12, 1982) (No. 80-1576) [hereinafter cited as Jurisdictional Statement].

For background on the U.S.L.P., see Donner \& Rothenberg, The Strange Odyssey of Lyndon LaRouche, 231 THE NATION 142 (1980); Foster, Teamster Madness, Mother Jones, Jan. 1982, at 28; N.Y. Times, Oct. 7, 1979, at 1, col. 4. These articles describe the U.S.L.P. as a cult-like political organization created and led by Lyndon LaRouche. The organization shifted its philosophy from the extreme left to the extreme right during the mid-1970's; throughout its history, however, it has used disruptive tactics. These tactics have included the infiltration and harass- 
nor the U.S.L.P. was affiliated with the university. Although Princeton had issued a "blanket invitation" to the public to walk through its campus, it had established more restrictive rules concerning solicitation and distribution of materials. ${ }^{18}$ The university required individuals and groups not affiliated with it to obtain its permission to engage in such activities. ${ }^{19}$ The university's policy was to deny such permission unless the person or group had been invited by a member of the university community. ${ }^{20}$

Although Schmid was aware of this rule, he neither sought nor received permission to distribute materials on campus. ${ }^{21}$ Accordingly, he was arrested and convicted of trespass. ${ }^{22}$ At the lower court level, Schmid claimed a violation of his free speech rights under both the state and federal constitutions. ${ }^{23}$ Because Princeton is a private university, the primary focus was on whether the campus was analogous to a "company town" under the doctrine of Marsh v. Alabama. ${ }^{24}$ If so, the court could treat the university's action as state action, and Schmid could assert a first amendment right to distribute leaflets on campus. ${ }^{25}$ Both of the lower courts

ment of groups it perceives as its enemies and, on occasion, the use of violence. Although Schmid's activities at Princeton were nondisruptive, a frequent party tactic is to invite violence by insulting people who refuse to buy the party's literature. A former party member told the Times that insults such as "pig" and "Nazi" are common. "They can get anybody to hit them in a second," he said.

18 Jurisdictional Statement, supra note 17 , at 4.

18 Id. These regulations have since been revised. See 84 N.J. at 539 \& n.2, 423 A.2d at 617 \& n.2; supra note 9.

20 Jurisdictional Statement, supra note 17, at 4.

2184 N.J. at $539,541,423 \mathrm{~A} .2 \mathrm{~d}$ at $617,618$.

$22 \mathrm{Id}$. at $541,423 \mathrm{~A} .2 \mathrm{~d}$ at 618 . Schmid was arrested by a member of the university security department. He was fined fifteen dollars plus costs. Id.

23 Princeton Brief, supra note 10, at 4 . The procedural history of the case is as follows: Schmid was tried and convicted in Princeton Borough Municipal Court. State v. Schmid, No. SC53264 (Princeton Borough Mun. Ct. Oct. 30, 1978), reprinted in Jurisdictional Statement, supra note 17, at 49a. A trial de novo by the New Jersey Superior Court, Law Division, also resulted in conviction. Order Adjudging Defendant Guilty, reprinted in Jurisdictional Statement, supra note 17, at 48a. Schmid appealed to the New Jersey Superior Court, Appellate Division. While the case was pending there, it was certified by the New Jersey Supreme Court, which then overturned Schmid's conviction. Princeton's petition for rehearing was denied without opinion, and the university appealed to the Supreme Court. Princeton Brief, supra note 10, at 4-5.

24326 U.S. 501, 507 (1946) ("Whether a corporation or a municipality owns or possesses the town the public in either case has an identical interest in the functioning of the community in such manner that the channels of communication remain free."). See State v. Schmid, No. SC53264 (Princeton Borough Mun. Ct. Oct. 30, 1978), reprinted in Jurisdictional Statement, supra note 17, at $49 \mathrm{a}$.

25 See, e.g., Hudgens v. NLRB, 424 U.S. 507, 513 (1976) ("It is, of course, a commonplace that the constitutional guarantee of free speech is a guarantee only against abridgment by government, federal or state."). 
concluded that Princeton did not fall within the Marsh doctrine, ${ }^{20}$ which the Supreme Court has narrowed significantly in recent years. ${ }^{27}$ The New Jersey Supreme Court strongly suggested that the lower courts were right in reaching this conclusion and that Schmid indeed did not have a first amendment right to distribute leaflets on Princeton's campus. ${ }^{28}$

Nevertheless, the New Jersey Supreme Court overturned Schmid's conviction, ${ }^{29}$ relying in part on a recent United States Supreme Court case, PruneYard Shopping Center v. Robins. ${ }^{30}$ PruneYard involved a group of high school students who were collecting signatures on a petition in a privately owned California shopping center. The Galifornia Supreme Court held that even if the students had no first amendment right to petition on private property, they did have such a right under the considerably broader free speech provisions of the state constitution. ${ }^{31}$ The United States Supreme Court affirmed the state court decision. ${ }^{32}$

Similarly, in State v. Schmid, ${ }^{33}$ the New Jersey Supreme Court

26 See Jurisdictional Statement, supra note 17, at 48a, 68a.

27 Id. 6la-68a. In Amalgamated Food Employees Local 590 v. Logan Valley Plaza, Inc., 391 U.S. 308, 316-20, 324-25 (1968), the Court appeared to extend the "company town" rationale to a privately owned shopping center. In Lloyd Corp. v. Tanner, 407 U.S. 551, 562-67 (1972), however, the Court held that people who distribute leaflets have a first amendment right to enter a privately owned shopping center only when the subject matter of the leaflets is related to the activities of the center and when no adequate alternative means of communication exist. Finally, in Hudgens v. NLRB, 424 U.S. 507 (1976), the Court overruled Logan Valley, stating that "the rationale of Logan Valley did not survive the Court's decision in the Lloyd case." Id. 518 (footnote omitted). It now appears that the "company town" doctrine is limited to the relatively rare situation in which private property "has taken on all the attributes of a town ..." Logan Valley, 391 U. S. at 332 (Black, J., dissenting); see Hudgens, 424 U.S. at 518-19.

28 See Schmid, 84 N.J. at 549-53, 423 A.2d at 622-24. Compare id. at 575-80, 423 A.2d at 637-39 (Schreiber, J., concurring) (unequivocally rejecting the idea that Princeton's action could be deemed state action) with id. at $546 \mathrm{n.5}, 423 \mathrm{A.2d}$ at 621 n.5 (majority opinion) (suggesting that a finding of state action might be reached more easily in a case such as Schmid, which involved the university's dealings with outsiders, than in a case involving the university's internal affairs).

29 Id. at 569, $423 \mathrm{~A} .2 \mathrm{~d}$ at 633.

30447 U.S. 74 (1980); see Schmid, 84 N.J. at 553, 423 A.2d at 624. PruneYard was decided between the time Schmid was argued and the date the New Jersey Supreme Court issued its decision.

31 Robins v. Pruneyard Shopping Center, 23 Cal. 3d 899, 908-11, 592 P.2d 341, 346-48, 153 Cal. Rptr. 854, 859-61 (1979). See also Alderwood Associates v. Washington Environmental Council, 96 Wash. 2d 230, 635 P.2d 109 (1981) (finding, under state constitution, a right for individuals to solicit signatures at a privately owned shopping mall).

32 PruneYard, 447 U.S. at 88.

3384 N.J. 535, 423 A.2d 615 (1980), appeal dismissed sub nom. Princeton Univ. v. Schmid, 50 U.S.L.W. 4159 (U.S. Jan. 12, 1982) (No. 80-1576). 
found it unnecessary to rely on the first amendment. It looked instead to the free speech provisions of the New Jersey Constitution. ${ }^{34}$ Like those of the California Constitution, the free speech guarantees of the New Jersey Constitution have no state action requirement..$^{35}$ They may therefore be interpreted as applying to private parties as well as to the state. In Schmid, the New Jersey court devised a three-part test to determine when state-guaranteed free speech rights are enforceable on private property. ${ }^{36}$ Applying the test to Princeton, the court held that those rights were enforceable on the university's property. ${ }^{37}$ Thus, even if Schmid had no first amendment right to distribute leaflets on Princeton's campus, the court held that he did have a state constitutional right to do so, subject to reasonable time, place, and manner regulations. ${ }^{38}$

In light of PruneYard, New Jersey's right to interpret its own constitution more broadly than the federal Constitution is not in doubt. Indeed, those who perceive a retrenchment in the area of civil liberties by the Supreme Court's majority have long applauded the trend toward relying on state constitutions to afford greater protection for civil liberties. ${ }^{39}$ The prospect also may ap-

34 "Every person may freely speak, write and publish his sentiments on all subjects being responsible for the abuse of that right. No law shall be passed to restrain or abridge the liberty of speech or of the press." N.J. Const. art. I, para. 6.

"The people have the right freely to assemble together, to consult for the common good, to make known their opinions to their representatives, and to petition for redress of grievances." Id. art. 1, para. 18.

35 See 84 N.J. at 559-60, 423 A.2d at 628 . Forty-four state constitutions have no state action requirement in their free speech provisions. Note, Private Abridgement of Speech and the State Constitutions, 90 YALE L.J. 165, 179 (1980) [hereinafter cited as Private Abridgment]. It has been suggested that the other six states could also protect speech on private property, either through legislation, see Cohen, PruneYard Shopping Center v. Robins: Past, Present and Future, 57 CrI.-KeNT L. REv. 373,387 (1981), or through judicial interpretation, see State v. Schmid, 84 N.J. at 557 n.8, 423 A.2d at 626 n.8. The first draft of what became the first amendment to the United States Constitution did not have a state action requirement. See 1 The Debates and Proceedings in the Congress of the UntTed States 452, 760 ( $\mathrm{J}$. Gales compiler 1834). Omitting a state action requirement, therefore, is not without precedent.

3684 N.J. at 563, 423 A.2d at 630 . For a detailed discussion of the three-part test, see infra notes 129-45 and accompanying text.

3784 N.J. at $563-66,423 \mathrm{~A} .2 \mathrm{~d}$ at $630-31$.

3884 N.J. at 568-69, 423 A.2d at 633. A recent decision, Pennsylvania v. Tate, 432 A.2d 1382 (Pa. 1981), takes a similar approach. In Tate, members of an antiwar group were arrested for trespassing when they distributed leaflets at a public symposium on crime prevention at a private college. The Pennsylvania Supreme Court overturned their trespass convictions, relying on the state constitution's free speech guarantees. $432 \mathrm{~A} .2 \mathrm{~d}$ at 1390-91; see PA. Const. art. 1, $\$ 7$. The court, however, did not mention academic freedom.

39 See, e.g., PruneYard, 447 U.S. at 91 (Marshall, J., concurring); Brennan, State Constitutions and the Protection of Individual Rights, 90 Harv. L. Rev. 489 (1977); Howard, State Courts and Constitutional Rights in the Day of the Burger 
peal to federalists who, while perhaps disagreeing with the substance of some state court decisions, would support a state's right to chart its own course. ${ }^{40}$

A state, however, cannot expand the state-derived rights of some individuals by infringing on the federally protected rights of others.1 In PruneYard, the Supreme Court held that California had not infringed on the shopping center owner's federally protected property rights; ${ }^{42}$ in Schmid, the New Jersey court seemed to assume that Princeton's property rights were not substantially greater than those of the shopping owner. ${ }^{43}$ PruneYard also held that California had not infringed on the petitioner's first amendment rights; ${ }^{44}$ the New Jersey court did not address Princeton's first amendment rights at all. Yet on appeal Princeton claimed to have first amendment rights much greater than those of other property owners, ${ }^{45}$ making its asserted institutional right of academic freedom sufficient to distinguish Schmid from PruneYard and to justify an opposite result. ${ }^{46}$

\section{The SCope of Academic Freedom}

A determination that institutions may claim a right of academic freedom requires an understanding of the Supreme Court's definition of that right as it applies to individuals. ${ }^{47}$ For the most part, the cases addressing the academic freedom issue have involved the

Court, 62 VA. L. Rev. 873 (1976); Project Report: Toward an Activist Role for State Bills of Rights, 8 Harv. C.R.-C.L. L. REv. 271 (1973); Private Abridgment, supra note 35 .

40 See, e.g., PruneYard, 447 U.S. at 81 (majority opinion by Justice Rehnquist). 41 See id.

42 Id. 82-85. See infra text accompanying notes 149-53.

4384 N.J. at 560-62, $423 \mathrm{~A} .2 \mathrm{~d}$ at $628-30$.

44447 U.S. at 85-88. But see id. 96-101 (Powell, J., joined by White, J., concurring in part and in the judgment, expressing reservations on first amendment holding).

45 See Princeton Brief, supra note 10, passim.

46 Id. 22-25.

47 "[D] doctrine has so far concerned protection of the rights of individual faculty members rather than those of institutions." Note, Academic Freedom and Federal Regulation of University Hiring, 92 HARv. L. REv. 879, 881 (1979) [hereinafter cited as Academic Freedom]. One author has defined academic freedom as "a right claimed by the accredited educator, as teacher and as investigator, to interpret his findings and to communicate his conclusions without being subjected to any interference, molestation, or penalization because these conclusions are unacceptable to some constituted authority within or beyond the institution." R. MAclver, ACADEMIC Freedom IN OUR TIME 6 (1955). 
refusal of teachers at state schools to comply with investigations or to sign loyalty oaths. ${ }^{48}$

These cases raise two questions. First, do teachers really enjoy any more protection than other public employees-that is, is academic freedom a special first amendment right, or is it simply what the first amendment is called when used to protect teachers? If it is the latter, then academic institutions may have no greater first amendment rights than other institutions, such as corporations or even shopping centers. ${ }^{49}$ Second, if a special first amendment right of academic freedom does indeed exist, what is its justification? If it attaches to teachers only as individuals, its extension to institutions may be difficult to justify. If, however, it attaches to teachers because of their role in society, then academic institutions should be similarly protected if they fill a similar role.

\section{A. Academic Freedom as a Special First Amendment Right}

The first question-whether academic freedom is a special concern of the first amendment-is difficult to answer with certainty. Most cases in which the Supreme Court has discussed academic freedom have concerned speech or associational activities that took place outside the classroom. ${ }^{50}$ In Keyishian $v$. Board of Regents,51

48 See, e.g., Keyishian v. Board of Regents, 385 U.S. 589 (1967); Sweezy v. New Hampshire, 354 U.S. 234 (1957); cf. Adler v. Board of Educ., 342 U.S. 485 (1952) (upholding law making membership in subversive groups grounds to terminate teachers and school employees).

Generally, only teachers at state institutions may invoke constitutional protection for their claims of academic freedom because the first amendment applies only to state action. Teachers at private institutions may, and often do, claim that the university administration has violated their rights of academic freedom. Such claims, however, are not constitutional; instead, they are often based on contractual rights. Perhaps the most effective sources of such protection at the nonconstitutional level are the tenure system and professional associations such as the American Association of University Professors. See generally Developments in the Law-Academic Freedom, 81 HARv. L. REv. 1045, 1084-1128 (1968).

49 See First Nat'l Bank of Boston v. Bellotti, 435 U.S. 765, 777 (1978) ("If the speakers here were not corporations, no one would suggest that the State could silence their proposed speech. It is the type of speech indispensable to decisionmaking in a democracy, and this is no less true because the speech comes from a corporation rather than an individual") (footnotes omitted). The shopping center owner in PruneYard Shopping Center v. Robins, 447 U.S. 74, 85 (1980), asserted his first amendment rights as an individual. Corporations that own shopping centers presumably would be able to assert first amendment rights as well.

50 See, e.g., Keyishian v. Board of Regents, 385 U.S. 589 (1967); Barenblatt v. United States, 360 U.S. 109 (1959). But see Sweezy v. New Hampshire, 354 U.S. 234 (1957) (contempt citation for refusal to answer questions about lecture delivered to class at state university).

51385 U.S. 589 (1967). 
for example, the Court held that state university professors could not be dismissed for refusing to comply with an unconstitutionally vague and overbroad state "anti-subversive" program. It seems fairly clear that the Court would have reached the same result if the individuals challenging the program had been state-employed plumbers, machinists, or cafeteria workers instead of teachers. ${ }^{52}$

52 See United States v. Robel, 389 U.S. 258 (1967) (invalidating statute prohibiting employment of subversives in defense facilities on grounds of overbreadth); Wieman v. Updegraff, 344 U.S. 183 (1952) (invalidating loyalty oath required of all state employees, including faculty and staff at state universities).

One commentator, writing in the early 1960's, felt that teachers' first amendment rights were being violated to a greater extent than those of other citizens. Academic freedom is violated, he wrote, when a teacher is punished for extracurricular speech for which other citizens could not constitutionally be punished. Murphy, Academic Freedom-An Emerging Constitutional Right, 28 LAw \& CONTEMP. Probs. 447, 468-69 (1963).

A teacher's right of free speech within the classroom actually may be more circumscribed than the on-the-job free speech rights of other public employees. Courts have shown concern that teachers of young children might indoctrinate or proselytize their students. See Keyishian, 385 U.S. at 624, 628 (Clark, J., dissenting); Adler v. Board of Educ., 342 U.S. 485, 493 (justifying laws directed at subversives on ground that it is especially important to prevent subversives from shaping young minds).

Apparently no Supreme Court cases deal directly with a teacher's right of free speech inside the classroom; a number of lower courts, however, have dealt with this issue by applying the standard set for students in Tinker v. Des Moines Indep. Community School Dist., 393 U.S. 503 (1969). In Tinker, the Supreme Court upheld the right of high school students to protest the Vietnam war by wearing black armbands in school. The Court held that a school cannot penalize students' exercise of first amendment rights without "a showing that the students" activities would materially and substantially disrupt the work and discipline of the school." Id. 513 (citations omitted). The Second Circuit applied this standard to allow a teacher to wear a black armband in class for similar reasons. James v. Board of Educ., 461 F.2d 566 (2d Cir.), cert. denied, 409 U.S. 1042 (1972); cf. Russo v. Central School Dist. No. 1, 469 F.2d 623 (2d Cir. 1972) (finding first amendment violation when teacher dismissed for standing silently during classroom recitation of pledge of allegiance), cert. denied, 411 U.S. 932 (1973); Hanover v. Northrup, 325 F. Supp. 170 (D. Conn. 1970) (similar case).

Even when there is no "disruption" according to the Tinker standard, however, some courts have rejected teachers' first amendment claims. See East Hartford Educ. Ass'n v. Board of Educ., 562 F.2d 856 (2d Cir. 1977) (en banc) (rejecting teacher's claim that his refusal to wear a tie in his English class constituted "symbolic speech"); Brubaker v. Board of Educ., 502 F.2d 973 (7th Cir. 1974) (upholding termination of teachers for distributing poem to eighth grade students extolling marijuana and joyous life style), cert. denied, 421 U.S. 965 (1975); Resetar v. State Bd. of Educ., $284 \mathrm{Md}$. 537, 399 A.2d 225 (upholding dismissal of teacher with history of intemperate conduct for calling his students "jungle bunnies"), cert. denied, 444 U.S. 838 (1979).

Most of these cases, however, involved elementary or secondary school teachers. Teachers at state colleges or universities are likely to have more freedom in their choice of curriculum and teaching method. In Cooper v. Ross, 472 F. Supp. 802 (E.D. Ark. 1979), an assistant professor at a state university claimed he was not rehired because of his Marxist beliefs. The court concluded that "at least in the context of a university classroom, Cooper had a constitutionally protected right simply to inform his students of his personal political and philosophical views." Id. 811 (footnote omitted). The court noted that it was expressing no view "whether the same expression by a teacher in a public grade school or high school classroom would also be constitutionally protected." Id. 811 n.5. But see Ollman 
Yet it is difficult to dismiss the Court's "academic freedom" language as mere rhetoric. Perhaps the first amendment rights at issue in these cases would have been vindicated had the individuals involved been plumbers, but members of the Court clearly have been particularly vehement in vindicating the rights of teachers. Justice Douglas's dissent in Adler v. Board of Education, ${ }^{53}$ in which the majority upheld a state loyalty program applied to teachers, is the first ${ }^{54}$ and one of the most powerful examples of such vehemence:

What happens under this law is typical of what happens in a police state. Teachers are under constant surveillance; their pasts are combed for signs of disloyalty; their utterances are watched for clues to dangerous thoughts. A pall is cast over the classrooms. There can be no real academic freedom in that environment. ${ }^{55}$

Later the same year, Justice Frankfurter, in a concurring opinion in Wieman v. Updegraff, ${ }^{56}$ echoed Justice Douglas's concern for academic freedom: "To regard teachers . . . as the priests of our democracy is . . . not to indulge in hyperbole." 57 By the time Sweezy v. New Hampshire ${ }^{58}$ was decided five years later, several members of the Supreme Court seemed ready to acknowledge academic freedom as a constitutional right, declaring:

The essentiality of freedom in the community of American universities is almost self-evident. ... To impose any strait jacket upon the intellectual leaders in our colleges and universities would imperil the future of our Nation. . . Teachers and students must always remain free to inquire, to study and to evaluate, to gain new maturity and understanding; otherwise our civilization will stagnate and die. ${ }^{69}$

v. Toll, 518 F. Supp. 1196, 1218, 1220 (D. Md. 1981) (rejecting Marxist professor's claim that state university president refused to appoint him department chairman because of his beliefs, holding that professor's beliefs, while protected, were not "motivating factors" in decision and noting that one outside evaluator said plaintiff would seek to "indoctrinate" students if he were hired).

53342 U.S. at 508-1I (Douglas, J., joined by Black, J., dissenting).

54 See Note, Academic Freedom-Its Constitutional Context, 40 U. Coro. L. REv. 600, 609 (1968) (noting this dissent as the first specific recognition by a Supreme Court Justice of the concept of academic freedom).

55342 U.S. at 510 .

56344 U.S. at $194-98$ (Frankfurter, J., joined by Douglas, J., concurring).

57 Id. 196.

58354 U.S. 234 ( 1957 ).

$59 \mathrm{Id}$. 250 (Chief Justice Warren announcing the judgment of the Court in an opinion joined by Justices Black, Douglas, and Brennan). 
Finally, in Keyishian, the Supreme Court stated that academic freedom is "a special concern of the First Amendment, which does not tolerate laws that cast a pall of orthodoxy over the classroom." 80

Thus, from Adler to Keyishian, the Court has come not only to recognize academic freedom as a constitutional right, but also to endorse a kind of heightened judicial vigilance over alleged infringements.

\section{B. The Teacher's Role in Society}

The Court's concern in the academic freedom cases appears to be that state laws and investigations would affect freedom of speech inside, as well as outside, the classroom. The Court's language indicates an apprehension that such infringement would have a chilling effect, not only on the speech of individual teachers, but also on the entire educational process. ${ }^{61}$ Thus in Keyishian, the Court stated that "[o]ur nation is deeply committed to safeguarding academic freedom, which is of transcendent value to all of us and not merely to the teachers concerned." 62 As one commentator has persuasively argued, the extra "weight" in the balance in the academic freedom cases is not the teacher's personal freedom, but society's interest in a lack of restriction of teaching. ${ }^{63}$ The Court, therefore, has seen fit to give added protection to the speech of teachers because of their role in society as innovators, questioners, experimenters, and gadflies.

\section{G. Academic Freedom as an Institutional Right}

As has been noted, ${ }^{64}$ the Supreme Court has not squarely held that the first amendment's protection of academic freedom extends to the autonomy of educational institutions as well as to the free speech rights of individual teachers. ${ }^{65}$ Nonetheless, the Court's

60385 U.S. at 603.

${ }^{61} \mathrm{~A}$ tension remains, however, between the vigilant judicial protection of outof-class speech and the much more limited protection accorded in-class speech. See supra note 52.

62385 U.S. at 603 (emphasis added).

63 See Note, supra note 54, at 608-11.

64 See supra note 47.

65 Private schools as institutions did receive some protection against state interference in a series of cases that reached the Supreme Court in the 1920's. These cases were decided, however, on due process rather than first amendment grounds. See Farrington v. Tokushige, 273 U.S. 284, 298-99 (1927) (extensive governmental regulation of private foreign language schools held to deny owners and patrons "reasonable choice and discretion in respect of teachers, curriculum and textbooks"); Pierce v. Society of Sisters, 268 U.S. 510, 533-36 (1925) (state law re- 
development of the doctrine of academic freedom in the individual context indicates that it logically could be extended to protect institutions. Such an extension could be justified on either of two grounds, both of which are based on the notion that teachers receive special protection because of the role they fill in society. ${ }^{.6}$ This Comment contends that either of these proposed concepts of institutional academic freedom would protect a university's right to exclude state-imposed ideas from the core aspects of its educational functions-primarily its classes and curriculum.

\section{The University's Vicarious Assertion of Individual First Amendment Rights}

The first of these concepts of academic freedom is perhaps the more limited one. It is suggested in part by Justice Powell's opinion in Regents of the University of California $v$. Bakke, ${ }^{67}$ in a passage that Princeton and others have interpreted as the first hint of Supreme Court support for an institutional right of academic freedom. ${ }^{68}$ Bakke involved a medical school admissions plan that set aside a certain number of places for minority applicants. Justice Powell, speaking for himself alone, found that a race-conscious admissions plan could be justified by the university's goal of attaining a diverse student body, which he found to be a "compelling" interest."9 "Academic freedom," he wrote, "long has been viewed as a special concern of the First Amendment. The freedom of a university to make its own judgments as to education includes the selection of its student body." 70

Although seemingly quite open-ended, ${ }^{71}$ when placed in con-

quiring all children to attend public school unreasonably interferes with liberty of parents); Meyer v. Nebraska, 262 U.S. 390, 401 (1923) (law forbidding teaching of any modern foreign language is an intrusion into liberty of parents and teachers).

66 See supra text accompanying notes 62-63. Court).

67438 U.S. 265, 269-320 (1978) (Powell, J., announcing the judgment of the

68 See Princeton Brief, supra note 10, at 7; Comment, Preventing Unnecessary Intrusions on University Autonomy: A Proposed Academic Freedom Privilege, 69 CAIIF. L. REv. 1538, 1546, 1547-48 (1981) [hereinafter cited as Proposed Privilege]; Academic Freedom, supra note 47 , at 882-85.

69438 U.S. at 314. Justice Powell's identification of diversity as a compelling interest in the university context appears in Part IV.D. of his opinion, a part in which no other Justice joined. Four other Justices found the admissions program justified by the university's goal of remedying discrimination in society as a whole. Id. 362 (Brennan, J., concurring in the judgment in part and dissenting in part, joined by Justices White, Marshall, and Blackmun).

70 Id. 312.

71 Even more open-ended is the following passage from Justice Frankfurter's concurring opinion in Sweezy, which Justice Powell cited with approval: 
text Justice Powell's concept of academic freedom appears considerably more circumscribed. First, Bakke involved a state university. It is difficult to see how an arm of the state can assert any first amendment rights of its own. Certainly it could not espouse a particular religious, ideological, or political viewpoint without violating the first amendment. ${ }^{72}$ Nor could it exercise its right to select its student body in order to exclude rather than include minority students. ${ }^{73}$

Perhaps Justice Powell actually was concerned with the first amendment rights of the students-specifically, their rights to associate freely with minority students. ${ }^{74}$ Justice Powell may have seen the state university as asserting vicariously, these aggregate individual first amendment rights. If so, his concept of an institutional right of academic freedom would protect the institution, whether private or public, only to the extent that it furthered these individual rights. ${ }^{75}$ In addition, Justice Powell's discussion of the institutional right-and that he discussed it in the context of a state university-suggests a second limitation: only those institutional policies promoting "diversity" and a "robust exchange of ideas" are to be protected by the first amendment. ${ }^{76}$ In short, students and teachers are protected because of their roles in society, and universities are to be protected to the extent that they enable students and teachers to fulfill these individual roles. ${ }^{77}$

It is the business of a university to provide that atmosphere which is most conducive to speculation, experiment and creation. It is an atmosphere in which there prevail 'the four essential freedoms' of a universityto determine for itself on academic grounds who may teach, what may be taught, how it shall be taught, and who may be admitted to study.

438 U.S. at 312. Justice Frankfurter was quoting the words of a group of South African scholars who were protesting racially exclusionary policies that their government had imposed. See Sweezy, 354 U.S. at 263. at 883 .

72 See Princeton Brief, supra note 10, at 9; Academic Freedom, supra note 47,

${ }^{73}$ See, e.g., Brown v. Board of Educ., 347 U.S. 483 (1954). Even private schools may be barred from refusing to admit black students. See Runyon v. McCrary, 427 U.S. 160, 168-75 (1976). Cf. Norwood v. Harrison, 413 U.S. 455 (1973) (states may not constitutionally provide free textbooks to segregated private schools).

74 Freedom of association has been termed a limited or peripheral first amendment right, applying only to the pursuit of goals "independently protected by the first amendment." L. Tribe, American Constitutional Law, \$12-23, at 702 (1978) (emphasis in original). Thus, students who want to attend segregated schools might not have a freedom of association claim because racial segregation is not a protected purpose.

75 Academic Freedom, supra note 47, at 883.

76 Id. 883-85.

${ }^{77}$ Justice Powell appeared to extend his view of institutional academic freedom in his dissenting opinion in Cannon v. University of Chicago, 441 U.S. 677, 730, 


\section{A University's Philosophy as a Form of Communication}

Although Justice Powell in Bakke appeared to endorse a broad right of academic freedom, ${ }^{78}$ Princeton acknowledged the limitations of this right as exercised by public educational institutions. ${ }^{79}$ It argued, however, that private universities have much broader first amendment rights than public universities: "What at first blush is difficult to understand is simply that the educational policy choices guaranteed to private universities by the First Amendment are denied to public ones for the same First Amendment reasons." 80 Although public universities cannot align themselves with particular philosophies, Princeton contended that in the private setting it is the very choice of such a philosophy that the first amendment protects. Thus, Princeton's argument suggests a second concept of academic freedom: that the effective owners of a university-its trustees and administrators-express their philosophies through their institutions. ${ }^{81}$ Such expression, Princeton argued, is protected by the first amendment. ${ }^{82}$ This concept of academic freedom harks back to the protection of the teacher's role in society, but it rests on the notion that the university's role as an institution is similar to the teacher's role as an individual. If this similarity in roles exists, institutions should enjoy as much independent first amendment protection as individuals.

In support of its argument, Princeton relied heavily on Miami Herald Publishing Co. v. Tornillo, ${ }^{83}$ drawing an implicit analogy between universities and newspapers as two institutions protected by the first amendment.84 In Tornillo, the Supreme Court struck

747 (1979) (Powell, J., dissenting from Court's finding of private right of action under title IX on grounds statute "trenches on the authority of the academic community to govern itself"). Cf. Lacovara, How Far Can the Federal Camel Slip Under the Academic Tent?, 4 J.C. \& U.L. 223, 232 (1977) (arguing that academic freedom should extend to institutions because the unfettered development of ideas by students and teachers cannot take place in a vacuum).

78 See supra notes 67-71 and accompanying text.

70 See Princeton Brief, supra note 10, at 9.

$80 \mathrm{Id}$. (emphasis in original).

81 Cf. W.F. BuCKuEY, GoD AND MAN AT YAJE 190 (195I) ("[I]n the last analysis, academic freedom must mean the freedom of men and women to supervise the educational activities and aims of the schools they oversee and support.").

82 See Princeton Brief, supra note 10, at 11.

83418 U.S. 241 (1974).

84 See Princeton Brief, supra note 10, at 7, 23-25. Because the press is specifically mentioned in the first amendment, it arguably may be entitled to greater protection than other institutions. But see First Nat'l Bank of Boston v. Bellott, 435 U.S. 765, 797-802 (1978) (Burger, C.J., concurring) for a rejection of this possibility: "The liberty encompassed by the Press Clause, although complementary 
down a Florida statute mandating a "right of reply" for political candidates who had been criticized by a newspaper; the law required the paper to publish the candidate's reply free of charge. As in Princeton University $v$. Schmid, , $^{5}$ the justification for a state-mandated right of access was that individuals need access to forums in which they can exercise their free speech rights. ${ }^{86}$ The Court declared, however, that the Florida law exacted "a penalty on the basis of the content of a newspaper" 87 and was an "intrusion into the function of editors"; 88 it concluded:

A newspaper is more than a passive receptacle or conduit for news, comment, and advertising. The choice of material to go into a newspaper, and the decisions made as to limitations on the size and content of the paper, and treatment of public issues and public officials-whether fair or unfair-constitute the exercise of editorial control and judgment. 89

If the analogy makes sense and a private university is similarly "more than a passive ... conduit for" the exchange of ideas between its students and faculty, then its educational decisions should be protected just as a newspaper's editorial decisions are.90 In

to and a natural extension of Speech Clause liberty, merited special mention simply because it had been more often the object of official restraints." Id. 800 .

Even if one assumes that the press does merit more first amendment protection than other institutions, Tornillo need not necessarily be limited to protecting the rights of newspapers. Once universities are brought within the constitutional doctrine of academic freedom, Tornillo also should be applicable to them. The academic freedom doctrine would confer an additional measure of first amendment protection on universities and thus elevate their constitutional status to that of newspapers.

8550 U.S.L.W. 4159 (U.S. Jan. 12, 1982) (No. 80-1576), dismissing appeal from State v. Schmid, 84 N.J. 535, 423 A.2d 615 (1980).

86 See 418 U.S. at 251-52.

87 Id. 256.

88 Id. 258.

89 Id. (footnote omitted).

$90 \mathrm{~A}$ number of commentators have remarked on the apparent inconsistency between Tornillo and Red Lion Broadcasting Co. v. FCC, 395 U.S. 367 (1969). Red Lion upheld the FCC's "fairness doctrine," which mandates a right of reply for an individual who has been the object of a personal attack over a broadcast station. The Court rejected the broadcasters' first amendment claims.

A review of the extensive literature attempting to reconcile Red Lion and Tornillo is beyond the scope of this Comment. See Van Alstyne, The Möbius Strip of the First Amendment: Perspectives on Red Lion, 29 S.C.L. REv. 539, 547 n.49 (1978) (listing articles). Van Alstyne suggests that broadcast media and newspapers are distinguishable because of the scarcity of usable broadcast frequencies. Through licensing, the government assigns these frequencies in exchange for the fiduciary duty of airing some programs on public issues. Id. 550-52. Van Alstyme notes that most of the commentators "supportive of Red Lion agree ... that the 
fact, the analogy does appear to hold true. Although many decisions a university makes are bound to be mundane and primarily administrative, basic decisions affecting teaching and curriculum may well reflect the institution's underlying educational philosophy. In deciding which courses to offer, which teachers to hire, ${ }^{91}$ even, perhaps, which extracurricular activities to support, a university's trustees and administrators are selecting certain options and rejecting others in accordance with some notion, whether implicit or explicit, of what is worthy of study and serious thought.

The analogy between universities and individual teachers involves similar considerations. Although universities are not typically perceived as innovators or gadflies-as individual teachers might be-they can and do perform these roles in their own way: An innovative school such as Antioch College can be as creative, ${ }^{92}$ in an institutional sense, as a scholar who formulates a new theory. Similarly, a university's decision to offer a course in Marxian economics in the midst of a hostile political climate should be just as worthy of protection as a professor's refusal to cooperate with a state investigation into vaguely defined "subversives." 93

Thus, returning to the Tornillo analogy, a private university's decision to offer a course in Marxian economics, like an editor's decision to publish an article criticizing a politician, is a decision protected by the first amendment. A state law mandating, for example, a "right of reply" for monetarists criticized in the university's Marxian economics course would be an intrusion similar to that declared unconstitutional in Tornillo. A law requiring that a specific course be introduced into the curriculum might even rise to the level of "compelled speech," which also has been held to violate the first amendment.94

It appears, then, that if Princeton's concept of institutional academic freedom-a university's educational philosophy as pro-

literal scarcity distinction is both necessary and sufficient to sustain the case alongside Tornillo." Id. 552 (footnote omitted). This peculiar characteristic of broadcast stations appears sufficient to distinguish them not only from newspapers but also from universities.

91 Cf. Proposed Privilege, supra note 68, at 1546-52 (compelled disclosure of university's confidential employment information implicates its rights of academic freedom); Academic Freedom, supra note 47, at 888-91 (university's hiring decisions are a form of protected speech).

92 See generally ANTroch CoLr.zge, MARYLAND (1977-79) 5, 12-15 (describing college's innovative programs).

${ }^{33} \mathrm{Cf}$. Sweezy v. New Hampshire, 354 U.S. 234 (1957) (professor's refusal to answer questions about his lectures protected by the first amendment).

${ }^{94}$ See West Virginia State Bd. of Educ. v. Barnette, 319 U.S. 624 (1943) (pledge of allegiance requirement violates first amendment). 
tected "communication"-is accepted, a university has a first amendment right to resist the state's imposition of ideas it does not choose to support. Under Tornillo, this is true regardless whether the state itself has dictated the content of the idea; an imposed "right of access" for outsiders' ideas would be just as unconstitutional as a state-mandated course.

If, alternatively, Justice Powell's view of institutional academic freedom is accepted, a private university's right to exclude ideas becomes somewhat more difficult, but not impossible, to justify. One of the two limitations suggested by Justice Powell's opinion is that the first amendment protects only those institutional policies that promote diversity. ${ }^{95}$ If this is read to mean diversity within the individual school, then clearly the exclusion of ideas would not merit protection. If, however, the word is read more broadly to mean diversity within society as a whole, an individual institution's decision to exclude ideas might well qualify as a protected one. The right to exclude or reject ideas is an essential part of the right to be different, whether in the institutional or individual context. ${ }^{.6}$ Thus, requiring each institution to accept a broad range of ideas, in the interest of internal diversity, may well lead to a decline in diversity among institutions. ${ }^{97}$ Such a decline in diversity over the past twenty years has in fact been documented; it has been attributed largely to the growth of publicly supported universities and the decline of smaller and more specialized private colleges. ${ }^{98}$ The creation of an enclave devoted to a specific ideology-a "school of thought" in a literal sense-may contribute to the "robustness" of the exchange of ideas between, if not within, institutions. ${ }^{90}$ An institution's right to exclude ideas also may survive another limitation inferable from Justice Powell's discussion: the requirement that a university be asserting vicariously the individual rights of its students and faculty in order to claim an institutional right of academic freedom. ${ }^{100}$ If a single institution's exclusion

95 See supra text accompanying notes $69 \& 76$.

${ }^{96}$ See, e.g., Wooley v. Maynard, 430 U.S. 705 (1977) (upholding refusal to display state motto on license plate); Barnette, 319 U.S. at 640-42 (school cannot compel "uniformity of sentiment").

97 Cf. C. PACE, The Demese of Drversity? 2 (1974) ("As each institution expands the range of its own programs, it may increase the diversity of its own clientele but at the same time decrease the difference between it and other institutions").

98 Id. 3.

99 Academic Freedom, supra note 47, at 885 .

100 See supra notes 74-75 and accompanying text. 
of ideas serves to increase diversity among institutions, ${ }^{101}$ it follows that recognition of an institution's right to exclude ideas broadens the range of educational choice available to individuals. Some students and teachers choose certain schools-for example, small liberal arts schools or schools with a certain political outlookfor the very reason that they limit themselves to a specific range of ideas or courses. The choice to attend such a school may itself be seen as an exercise of first amendment freedoms ${ }^{102}$-whether viewed as "symbolic speech" or as freedom of association-and it can be exercised effectively only if diversity among institutions is protected. ${ }^{103}$

Although a basis for an institutional right of academic freedom therefore may be discerned, the scope of this right is not clear. A university should not be able to immunize any action it takes simply by invoking the words "academic freedom." This Comment does not contend that Princeton, or any other private institution, could claim a first amendment right either to exclude minorities from its student body 104 or to engage in discriminatory faculty hiring practices. ${ }^{105}$ Princeton, however, claimed a right to exclude ideas,

101 See supra note 97 and text accompanying note 99.

102 The right to choose which school to attend also may be considered part of the guarantee of "liberty" in the due process clause. In Pierce v. Society of Sisters, 268 U.S. 510 (1925), the Supreme Court ruled that a state law requiring parents to send their children to public school "unreasonably interferes with the liberty of parents . . . to direct the upbringing and education of [their] children." Id. 534-35. The Court added that a state lacks any general power "to standardize its children by forcing them to accept instruction from public teachers only." Id. 535.

103 At least one important difference between the Powell approach to academic freedom and Princeton's view of it remains. Under the Powell approach, a university could not assert a right of academic freedom against its own members, because its right is derived from theirs. Thus, if a rule like Princeton's were applied by a state university against its students and faculty, the university could not defend the rule on first amendment "academic freedom" grounds. Rather, the students and faculty could attack the rule on first amendment grounds because their own rights of free speech would be violated.

104 Cf. Runyon v. McCrary, 427 U.S. 160 (1976) (private schools may not exclude black students). See generally H. Frnendey, The Dartaouth Correge Case and the Public-Private Penumbra 11 (n.d.) (assuming that the states constitutionally may prohibit religious as well as racial discrimination in private universities).

105 Claims of employment discrimination against universities are notoriously diffcult to win. University employment and tenure decisions are largely subjective, presenting the plaintiff with difficult issues of proof under title VII. Courts are wary of second-guessing decisions made on academic grounds. See, e.g., Faro v. New York Univ., 502 F.2d 1229, 1231-32 (2d Cir. 1974); Johnson v. University of Pittsburgh, 435 F. Supp. 1328, 1371 (W.D. Pa. 1977); Lewis v. Chicago State College, 299 F. Supp. 1357, 1359 (N.D. Ill. 1969). More recently, the Second Circuit has lamented that its Faro opinion is widely cited "for the broad proposition that courts should exercise minimal scrutiny of college and university employment practices. 
not people. ${ }^{106}$ In practice, courts and legislatures have refrained -with a few notorious exceptions ${ }^{107}$-from intervening in internal curriculum decisions, even where public institutions are con-

... This anti-interventionist policy has rendered colleges and universities virtually immune to charges of employment bias, at least when that bias is not expressed overtly." Powell v. Syracuse Univ., 580 F.2d 1150, 1153 (2d Cir.), cert. denied, 439 U.S. 984 (1978). See also Note, Tenure and Partnership as Title VII Remedies, 94 Harv. L. Rev. 457, 475 (1980); Comment, Subjective Employment Criteria and the Future of Title VII in Professional Jobs, 54 U. DET. J. URB. L. 165, 213 (1976) ("Given the restrictions imposed by courts in university cases, only the most qualified plaintiffs who are judged by the most blatantly biased evaluators could hope to succeed.").

Allowing the introduction of an academic freedom defense in employment discrimination actions would place yet another obstacle in the plaintiff's path and lend itself to misuse by the defendant. One state university, for example, argued that its denial of tenure to a woman professor was based not on sex discrimination but on its belief that the plaintiff's academic interest in women's issues was too "trendy." Lynn v. Regents, University of California, 21 Fair Emp. Prac. Cas. (BNA) 313,314 (C.D. Cal. 1979). The district court found this argument convincing, implying that it showed that the university's tenure decision was protected by "academic freedom." Id. 315. The court of appeals, however, reversed, finding that the university's "disdain for women's issues, and . . . diminished opinion of those who concentrate on those issues, is evidence of a discriminatory attitude towards women." (footnote omitted). Lymn v. Regents of the University of California, 656 F.2d 1337, 1343 (9th Cir. 1981). Cf. In re Dinnan, 661 F.2d 426 (5th Cir. 1981) (in employment discrimination case, "academic freedom" does not protect faculty member against discovery of his vote on tenure for plaintiff); Kunda v. Muhlenberg College, 621 F.2d 532, 547, 549 (3d Cir. 1980) (rejecting college's claim that trial court's award of conditional tenure in sex discrimination suit violated college's academic freedom). But see Gray v. Board of Higher Education, 92 F.R.D. 87 (S.D.N.Y. I981) (confidentiality of faculty peer review system protected against discovery in employment discrimination suit; decision on granting tenure embodies essence of academic freedom).

See generally Lacovara, supra note 77, at 225-26, 230, 233-35; Oaks, A Private University Looks at Government Regulation, 4 J.C. \& U.L. 1, 3-4 (1976); Proposed Privilege, supra note 68, at 1548-55; Academic Freedom, supra note 47, at 888-90.

106 One might argue that in fact Princeton is excluding people rather than ideas because its rule applies only to outsiders. If a student or faculty member were to engage in expressive activity on Princeton's campus, however, the university presumably would apply its own intemal disciplinary sanctions. Only when a stranger-who is immune to Princeton's internal sanctions-undertakes the expressive activity do the state's trespass laws necessarily become involved. In addition, the university rules in effect at the time of Schmid's arrest merely required an invitation from a student or a faculty member as a prerequisite to allowing expressive activity by strangers. Thus, Princeton's apparent objective was not to exclude certain people but certain ideas-that is, those ideas that members of the university community had no interest in hearing.

107 See, e.g., Epperson v. Arkansas, 393 U.S. 97 (1968) (law forbidding teaching of evolution in state schools violates first amendment's establishment clause); see also Kay v. Board of Higher Educ., 173 Misc. 943, 18 N.Y.S.2d 821 (Sup. Ct.), aff'd mem., 259 A.D. 879, 20 N.Y.S.2d 1016 (1940). In Kay, a taxpayer challenged Bertrand Russell's appointment as Professor of Philosophy at the City College of New York. The court upheld the challenge, relying in part on Russell's lack of good "moral character" as evidenced by his views on sex. Id. at 948-49, 18 N.Y.S.2d at 827 . In a statement clearly illustrating the dangers of judicial intervention in this area, the court said, "[a]cademic freedom does not mean academic license. It is the freedom to do good and not to teach evil." Id. at 951, 18 N.Y.S.2d at 829 . 
cerned.108 Such restraint indicates respect for the autonomy of educational institutions.

\section{Summary}

"Academic freedom" is more than merely a label for the first amendment as applied to teachers. It attaches to teachers because of their role in society and gives them heightened protection. One argument favoring an institutional right of academic freedom is that a university is asserting vicariously the individual rights of its teachers and students. This institutional right, however, is limited: it must be exercised in the interests of promoting diversity and a robust exchange of ideas.

A second argument favoring such an institutional right is that a university's choice of educational philosophy is a form of communication; thus, first amendment protections extend to it. Analogizing its educational decisions to a newspaper's editorial decisions, Princeton argued that a state-mandated right of access to its campus is unconstitutional..$^{109}$

Princeton's decision to exclude unwanted ideas may be justified under either concept of institutional academic freedom. The limits on this institutional right of academic freedom, however, remain to be explored.

\section{Academic Freedom and Property Rights}

In its broadest sense, education is not only the communication of ideas, but also the creation of an environment.

Teaching and exchange of ideas occur not only in the classroom but on the walkways and grounds of the campus, where students speak to students, professors with professors, and professors with students. In what manner and to what extent persons who are not members of the University community may contribute to this educational process are educational decisions. ${ }^{110}$

108 See Proposed Privilege, supra note 68, at 1547; Developments in the LawAcademic Freedom, 81 Harv. L. Rev. 1045, 1050-55 (1968). In Epperson, the Supreme Court said:

Judicial interposition in the operation of the public school system of the Nation raises problems requiring care and restraint. . . Courts do not and cannot intervene in the resolution of conflicts which arise in the daily operation of school systems and which do not directly and sharply implicate basic constitutional values.

393 U.S. at 104 (footnote omitted).

109 See supra text accompanying notes 83-91.

110 Princeton Brief, supra note 10, at 13. 
Decisions concerning the ideas that may be expressed on a campus may have some effect on a university's educational environment. Whether such decisions are so central to education that they merit first amendment protection, however, is another question.

The New Jersey Supreme Court based its State v. Schmid 111 decision on the state constitution's free speech provision, which has no state action requirement, ${ }^{112}$ and not on the first amendment, which does.113 The decision is therefore unlikely to impinge on the university's curriculum decisions or its dealings with students and faculty. If the court had found state action in Schmid, the university might have been required to remain ideologically neutral and to comport with the requirements of due process in its dealings with students and possibly with tenured faculty. ${ }^{114}$ The Schmid opinion, however, is confined to the university's relationship to outsiders, and only to those areas of the university's property where the public has been invited. ${ }^{115}$

Princeton, however, sought to invoke the first amendment to exclude unwanted ideas from its campus entirely, contending that its property is "devoted to expressive purposes" and therefore is protected by the first amendment. 116 In two previous cases, the Supreme Court has struck down laws requiring property to be used

11184 N.J. 535, 423 A.2d 615 (1980), appeal dismissed sub nom. Princeton Univ. v. Schmid, 50 U.S.L.W. 4159 (U.S. Jan. 12, 1982) (No. 80-1576).

112 Id. at $553,560,423 \mathrm{~A} .2 \mathrm{~d}$ at 624,628 . See supra notes $34-35$ and text accompanying note 35 .

113 Even before the Supreme Court began narrowing the state action concept, see supra note 27 , courts were reluctant to apply it to private universities, largely because of the difficulties of limiting the consequences of such a finding. Compare Greene v. Howard Univ., 271 F. Supp. 609, 612-13 (D.D.C. 1967) (refusing to find state action by a private university merely on the basis of partial federal funding because of difficulties of limiting consequences of such a finding) with Guillory v. Administrators of Tulane Univ., 203 F. Supp. 855, 859 (E.D. La. 1962) (opinion of Skelly Wright, J.) (dictum) (suggesting that schools and colleges, whether public or private, come within reach of fourteenth amendment because they perform a public function).

At least one commentator has urged that private universities should be subject to the strictures of the fourteenth amendment because they, like company towns and unlike shopping centers, have the power to infringe not only first amendment rights but also those rights guaranteed by other constitutional provisions. See Schubert, State Action and the Private University, 24 Rutcens L. REv. 323, 327-30 (1970).

114 See Goss v. Lopez, 419 U.S. 565 (1975) (public school students threatened with brief disciplinary expulsions have right to informal hearing). See generally 1 N. Dorsen, P. Bender \& B. Neutorne, Political and Crvm Rights in the United STATES 862-69 (4th ed. 1976).

115 See Schmid, 84 N.J. at 546 n.5, 423 A.2d at 621 n.5 (suggesting a "less rigorous standard" for state action when a private university's dealings with outsiders, rather than its internal affairs, are at issue).

116 See supra text accompanying notes 12-14. 
for an "expressive purpose" with which its owner did not agree. In Wooley v. Maynard, , $^{117}$ the Court struck down a New Hampshire law requiring the slogan "Live Free or Die" to be displayed on state license plates. The Court held that the state may not "constitutionally require an individual to participate in the dissemination of an ideological message by displaying it on his private property in a manner and for the express purpose that it may be observed and read by the public." 118 In Miami Herald Publishing Co. v. Tornillo, ${ }^{119}$ the Court struck down a Florida law requiring newspapers to publish rebuttal to personal attacks as an infringement on first amendment rights, even though the state did not mandate a specific message. Property rights in both cases were only incidental to first amendment rights.

The property involved in Wooley and Tornillo differs in one crucial respect from the university campus involved in Schmid. License plates and newspapers are tangible items that, partly because they have words printed on them, actually communicate a message; a university's campus is merely the setting in which communication takes place. Although a university may use its property for expressive purposes, it cannot be said to be "speaking through" its property. "Free speech" has been defined to include many different methods of communication, but the common characteristic of these methods is that they all involve some kind of activity. ${ }^{120}$ The mere ownership of property that is not itself used to communicate ideas strains the definition of "activity." 121

117430 U.S. 705 ( 1977 ).

118 Id. 713.

119418 U.S. 241 (1974).

120 See generally Emerson, First Amendment Doctrine and the Burger Court, 68 CAIIF. L. REv. 422, 431-32 (1980) (various definitions of conduct protected by the first amendment).

121 Justices Rehnquist and Blackmun dissented in Wooley on the ground that the required display of a license plate is not an affirmative expressive act. 430 U.S. at 720-21. The majority conceded that, compared to the pledge of allegiance requirement struck down in West Virginia State Bd. of Educ. v. Barnette, 319 U.S. 624 (1943), the display of a license plate is a "passive act." Nonetheless, the Court concluded that

the difference is essentially one of degree. Here, as in Barnette, we are faced with a state measure which forces an individual, as part of his daily life-indeed constantly while his automobile is in public view-to be an instrument for fostering public adherence to an ideological point of view he finds unacceptable.

430 U.S. at 715.

Princeton's claim might be viewed as an assertion that its property management is protected by the first amendment-arguably a more active endeavor than property 
The ownership of property is often an essential prerequisite to the exercise of civil liberties, ${ }^{122}$ and the dichotomy between personal rights and property rights has been declared a false one. ${ }^{123}$ Nonetheless, property does not automatically become imbued with its owner's constitutional rights. A university might argue persuasively for preventing strangers from expressing ideas in its classrooms, but not because its desks and chairs are protected by the first amendment. Rather, such exclusion is justifiable because classrooms are not generally open to the public. Expressive activity in the classroom by strangers would interfere with the university's communication of its own message.

If a university's communication merits first amendment protection, perhaps its right of academic freedom should extend only so far as is necessary to prevent interference with that communication. ${ }^{124}$ Expressitve activity by strangers on a private university campus, subject to suitable time, place, and manner restrictions, ${ }^{125}$ should no more interfere with this communication than it does on a public campus, although the content of the private university's message may be different. A complete ban on outside speakers would not be necessary to protect the university's ability to communicate. ${ }^{128}$ Students' privacy interests and the maintenance of an atmosphere conducive to study can be protected by prohibiting

ownership. Nevertheless, decisions about property management are too remote from core educational concerns to be clothed with first amendment protection.

122 See Van Alstyne, The Recrudescence of Property Rights as the Foremost Principle of Civil Liberties: The First Decade of the Burger Court, 43 LAw \& Contemp. Probs. 66, 73 (Summer 1980). Van Alstyne saw the Supreme Court's grant of certiorari in PruneYard Shopping Center v. Robins, 447 U.S. 74 (1980), as a further indication of the "recrudescence of libertarian thought that identifies liberty with private property, liberty with prerogatives of property-to exclude from it, to contract with reference to it, to identify it as part of oneself."

123 Lynch v. Household Finance Corp., 405 U.S. 538, 552 (1972) (relief under 42 U.S.C. 1983 is not limited to "personal" rights, as opposed to "property" rights).

124 Cf. Runyon v. McCrary, 427 U.S. 160, 176 (1976) (school's communication of its belief in segregation is protected, but admission of black students will not impede that communication).

125 See Grayned v. City of Rockford, 408 U.S. 104, 116 (1972) (time, place, and manner regulations dictated by nature and normal use of property).

126 Cf. Van Alstyne, Political Speakers at State Universities: Some Constitutional Considerations, 111 U. PA. I. Rev. 328, 338-40 (1963) ("It would be extremely farfetched to assert that a university's educational purpose is totally circumscribed by its curriculum, so that even invited speakers do not contribute to its primary function."); Note, Campus Pamphleteering: The Emerging Constitutional Standards, 5 J.L. REF. 109, 112 (1971) (a university is justified in "exclud[ing] some areas from the public forum category"). 
commercial transactions or political canvassing in university dormitories, ${ }^{127}$ or perhaps by excluding commercial activity altogether. ${ }^{128}$

In State v. Schmid, the New Jersey Supreme Court formulated a test to determine when the state constitution allows free speech rights to be enforced on private property. The test considers three factors:

(1) the nature, purposes, and primary use of such private property, generally, its "normal" use, (2) the extent and nature of the public's invitation to use that property, and (3) the purpose of the expressional activity undertaken upon such property in relation to both the private and public use of the property. ${ }^{129}$

The court concluded that Princeton had invited the public to use its facilities and that Schmid's activities were "not incompatible with either Princeton University's professed educational goals or the University's overall use of its property for educational purposes." 130 Thus, the court held, Schmid had a right to speak on Princeton's campus, subject only to reasonable time, place, and manner regulations. ${ }^{131}$

The Schmid opinion contemplates substantial deference to university discretion in assessing the reasonableness of its time, place, and manner rules, out of regard for universities' "paramount role as vehicles of education and enlightenment." 132 The court found, however, that the university regulations applied to Schmid were unreasonable because they "contained no standards, aside from the requirement for invitation and permission, for governing the actual exercise of expressional freedom." ${ }^{133}$

127 See American Future Systems, Inc. v. Pennsylvania State Univ., 618 F.2d 252, 257-59 (3d Cir. 1980) (transaction of sales with groups of students in dormitories may constitutionally be banned); Brush v. Pennsylvania State Univ., $489 \mathrm{~Pa}$. 243,414 A.2d 48 (1980) (regulation of political canvassing in residence halls is constitutional).

128 Although Schmid was selling as well as distributing his materials, his primary activity apparently was political rather than commercial.

12984 N.J. at $563,423 \mathrm{~A} .2 \mathrm{~d}$ at 630 .

$130 \mathrm{Id}$. at $565,423 \mathrm{~A} .2 \mathrm{~d}$ at 631 (footnote omitted).

131 See id. at 567-68, $423 \mathrm{~A} .2 \mathrm{~d}$ at $632-33$.

132 Id. at 567, $423 \mathrm{~A} .2 \mathrm{~d}$ at 632 . In dictum, the court even approved the revised regulations Princeton voluntarily instituted after Schmid's arrest. Id. at $539 \mathrm{n.2}$, 568,423 A.2d at 617 n.2, 633 . See supra note 9 .

133 Id. at 567, $423 \mathrm{~A} .2 \mathrm{~d}$ at 632 . The New Jersey Supreme Court made no reference to any first amendment rights on Princeton's part but did state:

Private educational institutions perform an essential social function and have a fundamental responsibility to assure the academic and general wellbeing of their communities of students, teachers and related personnel. At 
If the court's test is read to require an examination only into the possibility of disruption of university activities, ${ }^{134}$ it would appear adequate to protect Princeton's legitimate concerns. The court, however, did not ask merely whether Schmid's activity was compatible with use of the property for educational purposesthat is, whether it would interfere with the university's normal functions. ${ }^{185}$ It also examined the compatibility of Schmid's activity with Princeton's particular educational philosophy. ${ }^{136}$ The court probably was pleased to find in Princeton's own regulations a ringing endorsement of the values of free speech and the exposure of students and faculty to a wide range of views. ${ }^{137}$ It may seem only logical for the court to have engaged in such an inquiry. In basing its decision on the content of Princeton's philosophy and its compatibility with Schmid's speech, however, the court was in fact infringing on the federal constitutional rights of both parties. ${ }^{138}$

It is a familiar principle of constitutional law that legislation or judicial action that is so vague as to have a chilling effect on protected speech violates the first amendment. ${ }^{139}$ Under the Schmid test, a university cannot be sure whether its particular philosophy -which is speech protected by the first amendment-will be deemed "compatible" with particular kinds of expressive activity. Even a standard that looks to compatibility between speech and an area's

a minimum, these needs, implicating academic freedom and development, justify an educational institution in controlling those who seek to enter its domain.

84 N.J. at 566, 423 A.2d at 632. Apparently, under the court's holding, considerations of institutional autonomy and "academic freedom" are relevant only to the reasonableness of time, place, and manner regulations.

${ }^{134} \mathrm{Cf}$. id. at 565-66, $423 \mathrm{~A} .2 \mathrm{~d}$ at 631 (no indication that Schmid's activities disrupted the University's essential operations).

135 Id. at 564-66, $423 \mathrm{~A} .2 \mathrm{~d}$ at 631 . Courts commonly look at the purpose of a particular area-even a publicly owned area-when deciding whether expressive activity may be barred. See, e.g., Wolin v. Port of N.Y. Auth., 392 F.2d 83, 89 (2d Cir.), cert. denied, 393 U.S. 940 (1968). One commentator has suggested, however, that the correct test in the educational setting is not the "primary purpose" of an area, but whether the proposed use will "intolerably burden the school's facilities." Van Alstyne, supra note 126, at 339 (footnote omitted).

13684 N.J. at 564-66, $423 \mathrm{~A} .2 \mathrm{~d}$ at 630-31.

137 The university's statement of its educational goals declares in part: "Free Speech and peaceable assembly are basic requirements of the University as a center for free inquiry and the search for knowledge and insight." Id. at 564, 423 A.2d at 630 .

138 The third part of the New Jersey court's test, see supra text accompanying note 129 , might be read to require a content-based distinction-that is, a person distributing leaflets espousing an "anti-education" viewpoint might be barred because his or her speech was incompatible with the educational use of the property. This interpretation would, like the court's application of the test, pose serious problems of content neutrality. See infra text accompanying notes $142-45$.

139 See, e.g., Keyishian v. Board of Regents, 385 U.S. 589, 603-04 (1967). 
"normal use" or "purpose" is vague; ${ }^{140}$ a compatibility standard based on an institution's educational philosophy may be unconstitutionally vague. 141

Moreover, the court, rather than Princeton, is making the compatibility judgment. This judicial involvement may infringe on the equal protection rights of the person distributing leaflets. When a speaker's first amendment rights are involved, courts and other governmental bodies are prohibited from making distinctions on the basis of the content of speech. ${ }^{142}$ When private property has been "opened" to public speech under a finding of state action, similar restrictions have been placed on the property owner. ${ }^{143}$ Because the New Jersey court did not find state action on Princeton's part, ${ }^{144}$ Schmid's first amendment rights are not at issue. Nevertheless, any denial of a state-created right-which would have occurred if Schmid's speech had been suppressed because of "incompatibility"-brings into play the equal protection clause of the fourteenth amendment. The Supreme Court has held that when a state denies a right of speech on the basis of the speech's content, equal protection scrutiny is exacting: "When government regulation discriminates among speech-related activities in a public forum, the Equal Protection Clause mandates that the legislation be finely tailored to serve substantial state interests, and the justifications offered for any distinctions it draws must be carefully scrutinized." 145

140 See Comment, The University and the Public: The Right of Access by Nonstudents to University Property, 54 CALIF. L. Rev. 132, 169 n.158 (1966) (standard of compatibility of speech with educational objectives of university too vague).

${ }^{141}$ See, e.g., Keyishian, 385 U.S. at $603-04$; NAACP v. Button, 371 U.S. 415, 438 (1963) (precision of regulation especially important in first amendment area).

142 See, e.g., Police Dep't of Chicago v. Mosley, 408 U.S. 92, 95 (1972); Cohen v. California, 403 U.S. 15, 24 (1971).

143 See Hudgens v. NLRB, 424 U.S. 507, 520 (1976); Marsh v. Alabama, 326 U.S. 501, 506-09 (1946).

In Hudgens, the Court relied on the prohibition against content-based regulation to demonstrate that its decision in Lloyd Corp. v. Tanner, 407 U.S. 551 (1972), had actually overruled Amalgamated Food Employees Local 590 v. Logan Valley Plaza, Inc., 391 U.S. 308 (1968). Hudgens, 424 U.S. at 518. See supra note 27. In Logan Valley, the Court allowed picketing of a store in a shopping center. In Lloyd, the Court refused to allow distribution of antiwar leaflets in a shopping center, distinguishing Logan Valley on the grounds that the content of the expressive activity in that case was related to the shopping center's operations. 407 U.S. at 562. In Hudgens, the Court noted that if a shopping center is deemed the "functional equivalent of a municipality," the Constitution does not permit content-based control of speech. 424 U.S. at 520.

144 See supra notes 24-28 and accompanying text.

145 Carey v. Brown, 447 U.S. 455, 461-62 (1980). See Police Dep't of Chicago v. Mosley; 408 U.S. $92,98-99$, 101 (1972). 
The New Jersey Supreme Court could have avoided these constitutional difficulties by excluding the third part of its test. ${ }^{146}$ The California Supreme Court in Robins v. Pruneyard Shopping Center relied on such a content-neutral test: the extent to which the property has been opened to public use and the extent to which the expressive activity will interfere with the normal use of the property. ${ }^{147}$ Because a university's first amendment rights of academic freedom do not extend to its property, ${ }^{148}$ the test to be applied should be the same as that which would apply to any property owner. "Educational philosophy" should not be a consideration.

\section{Constitutional Claims of a Noncommercial Property OWNER}

Although a university does not have special first amendment rights in the use of its property, its constitutional interests as a noncommercial property owner are not necessarily identical to those of a shopping center owner. The shopping center owner in PruneYard Shopping Center $v$. Robins advanced two lines of defense, one based on his property rights and the other on his individual first amendment rights. ${ }^{149}$ His property claims were that the state court's decision was a taking of property without just compensation and a deprivation of property without due process of law.150 His first amendment claim was based on the theory that "a private property owner has a First Amendment right not to be forced by the State to use his property as a forum for the speech of others." 151

\section{A. The Property Arguments}

The Supreme Court, in rejecting the property claims, spoke solely in terms of commercial property. When noncommercial property is involved, as in Princeton University $v$. Schmid, ${ }^{162}$ a different rule may prevail.

In PruneYard, for example, the Court found that requiring public speech in a shopping center was not a taking without just

146 See supra note 129 and accompanying text.

14723 Cal. 3d 899, 905, 909-10, 592 P.2d 341, 344, 347, 153 Cal. Rptr. 854, 857, 860 (1979), aff'd, 447 U.S. 74 (1980). 120-23.

148 See supra text following notes 119 \& 123 and text accompanying notes

149447 U.S. $74,80-88$ (1980).

150 Id. 82-85.

151 Id. 85 (footnote omitted).

15250 U.S.L.W. 4159 (U.S. Jan. 12, 1982) (No. 80-1576), dismissing appeal from State v. Schmid, 84 N.J. 535, 423 A.2d 615 (1980). 
compensation: the shopping center's owners had failed to show that the " "right to exclude others" "was "essential to the use or economic value of [the] property ... ." 153 Commercial property owners derive economic benefits from opening their property to the public; imposing public obligations on them in exchange for these benefits is perhaps justifiable. On the other hand, because universities are noncommercial and ostensibly devoted to study and research, unrestricted access by outsiders may cause a significant reduction in university property value. In light of such a reduction, a court might find a taking without just compensation. Thus, noncommercial property owners may be granted greater protection. ${ }^{154}$

An argument may well exist, however, for affording more protection to commercial than to noncommercial owners. Noncommercial owners who do not wish to host expressive activity may simply close their property to the public. But this may not be a viable option for most commercial property owners. In addition, some noncommercial properties, including some university campuses, may be better suited to dedication as "public forums" than some shopping centers. The location and landscaping of a campus may make it a natural gathering place for speakers and listeners. Under this line of reasoning, a university's property rights challenge would fail. A claim such as Princeton's would not be sufficient to prevent the state from interfering on behalf of an individual speaker.

\section{B. The First Amendment Claim}

The Court's discussion of the shopping center owner's first amendment rights in PruneYard has been identified as more problematic than its discussion of his property rights. ${ }^{155}$ The Court rejected the claim that a private property owner has a first amendment right not to be forced by the state to use his property for the speech of others. ${ }^{156}$ Justice Powell, in a concurring opinion, ex-

153447 U.S. at 84. The due process test the Court applied requires that the governmental action not be "unreasonable, arbitrary or capricious" and that there be a "real and substantial relation" between that action and a legitimate state interest. Id. 84-85 (quoting Nebbia v. New York, 291 U.S. 502, 523, 525 (1934)). This test would seem to apply equally to universities and shopping centers because the ends (promoting free speech) and the means (opening private property to public speech) are the same in both instances.

154 This argument might apply equally, if not with greater force, to such private nonprofit institutions as museums and art galleries.

155 See, e.g., Comment, PruneYard Shopping Center v. Robins, 9 HorstrA L. REv. 289, 307-08 (1980).

156447 U.S. at 85-88. 
pressed serious reservations about the breadth of this holding. ${ }^{107}$ He stressed that the holding should be limited to the large suburban shopping center actually involved in the case and noted that "[s]ignificantly different questions would be presented if a State authorized strangers to picket or distribute leaflets in privately owned, freestanding stores and commercial premises." 158

Justice Powell identified two potential problems. First, if the establishment were smaller, patrons might assume that the owner shared the views expressed by strangers. Second, apparently regardless of the establishment's size, the owner might find the views expressed so repugnant that he or she would feel compelled to respond. ${ }^{159}$ The Constitution, Justice Powell noted, protects an individual's " 'right to refrain from speaking at all." "160

Assuming that a university can assert first amendment rights similar to those of an individual property owner, Justice Powell's concerns may be applied to the Schmid case. His first concern is unlikely to create problems on a large university campus. Strollers on Princeton's campus probably would not assume that the university had lent its official support to the United States Labor Party simply because of Schmid's distribution of leaflets on campus. On a smaller campus, however, the possibility of such confusion is somewhat more likely. Nevertheless, the primary targets of expressive activity on any campus are bound to be the students, who are likely to be familiar with the administration's official views.

A more serious problem may be the possibility of repugnant ideas. Should a predominantly black university, for example, be required to allow the $\mathrm{Ku}$ Klux Klan to hand out leaflets? ${ }^{181}$ If it permits outside groups to use its auditorium, should it be required

157 Id. 96-101 (Powell, J., joined by White, J., concurring in part and in the judgment).

158 Id. 96.

159 Id. 99-100.

$100 \mathrm{Id} .99$ (quoting Wooley v. Maynard, 430 U.S. 705, 714 (1977)). Justice Powell also said that the Constitution protects the "freedom to maintain [one's] own beliefs without public disclosure." 447 U.S. at 100 (quoting Abood v. Detroit Bd. of Educ., 43I U.S. 209, 241 (1977)).

161 Cf. 447 U.S. at 99 (Powell, J., concurring):

A minority-owned business confronted with leafleteers from the American Nazi Party or the Ku Klux Klan, a church-operated enterprise asked to host demonstrations in favor of abortion, or a union compelled to supply a forum to right-to-work advocates could be placed in an intolerable position if state law requires it to make its private property available to anyone who wishes to speak. 
to rent available space for a Klan rally? ${ }^{162}$ Results such as these obviously would be disturbing, but once the state becomes involved in the decisionmaking process, questions of repugnance should not be allowed to determine the outcome. ${ }^{163}$ Any judicial test that relied on incompatibility between a property owner's views and those of an outside speaker would suffer from constitutional defects similar to those of the test applied in State $v$. Schmid. ${ }^{164}$ A court might, however, find that the property has not been opened to public use. Alternatively, a court might focus on the size of an establishment, imposing a "public forum" status only on large blocks of private property. ${ }^{165}$ Once a court has found private property to be a public forum, only two constitutional approaches would seem to be open to it. First, the court could find the speech to be incompatible with the use of the property. ${ }^{168}$ Second, it could punish the speaker if it found the speech posed a "clear and present danger." 168

Hence, both arguments advanced by the property owner in PruneYard also would fail in a case involving noncommercial property. Whether commercial property, such as a shopping center, or noncommercial property, such as a university campus, is involved, the PruneYard rationale may prevail.

\section{ConcLusion}

States should be able to require private universities that have opened their property to public use to host expressive activity by strangers without violating the universities' constitutionally protected free speech or property rights. Moreover, absent state in-

162 In the auditorium situation, the public at large is perhaps more likely to mistake the views of an outside group for those of the university. In addition, the renting of an auditorium appears to cross the line between passivity and activity, and the school might argue that its decisions to whom it will rent constitute protected speech. But see Southeastern Promotions, Itd. v. Conrad, 420 U.S. 546 (1975) (denial of municipal facilities held to be a prior restraint).

163 See supra notes $142-45$ and accompanying text.

164 Id.

105 Perhaps the only way to accommodate Justice Powell's concerns is to focus solely on the size of the establishment. Thus a black shopping center owner could not exclude the Klan, no matter how repugnant he found its views, but a black storeowner might. See generally Cohen, supra note 35, at 392-93.

166 See, e.g., Adderley v. Florida, 385 U.S. 39, 46-48 (1966) (peaceful demonstration on grounds of jail not protected by first amendment); Brown v. Louisiana, 383 U.S. 131, 142 (1966) (silent protest in library permissible because not disruptive of library's activities).

167 See, e.g., Brandenburg v. Ohio, 395 U.S. 444, 447 (1969); Schenck v. United States, 249 U.S. 47,52 (1919). 
terference with its core educational decisions, a university cannot rely on the constitutional doctrine of academic freedom to exclude strangers from its campus. In light of these conclusions, arguments such as those Princeton advanced in Princeton University $v$. Schmid ${ }^{168}$ are likely to fail.

Policy considerations, however, may lead the states to be cautious in enforcing speech rights on university property. The prospect of universities declaring their campuses off-limits to the public in order to exclude undesirable expression, while perhaps unlikely, is not particularly appealing. Moreover, the incentives to open other kinds of private property to public expression may not apply so strongly to universities. Shopping centers, for example, have been seen as appropriate areas for public speech because they have replaced downtown business districts in many parts of the country. Some suburban shopping malls now include not only retail stores but also meeting rooms, churches, post offices, and law offices, leading one observer to compare the modern shopping center to the traditional village green.169 Access to shopping centers may be crucial in reaching large groups of people efficiently and inexpensively. ${ }^{170}$

Universities have not taken the place of traditional public forums in recent years. On the other hand, the number of public forums need not be fixed permanently by tradition. A state's interest in promoting free speech may justify its adding to, rather than merely preserving, areas where the public has a right to speak.

16850 U.S.L.W. 4159 (U.S. Jan. 12, 1982) (No. 80-1576), dismissing appeal from State v. Schmid, 84 N.J. 535, 423 A.2d 615 (1980).

169 Comment, PruneYard Shopping Center v. Robins, 9 Hofstra L. Rev. 289, $310(1980)$.

170 The California Supreme Court cited statistics on the "growing importance of the shopping center" in Robins v. Pruneyard, 23 Cal. 3d 899, 907, 592 P.2d 341, 345, 153 Cal. Rptr. 854, 858 (1979), aff'd, 447 U.S. 74 (1980). But see Cohen, supra note 35 , at 395 , arguing that today it is not so important that shopping centers be open to public speech because new "public forums"- such as broadcast stationshave arisen.

A similar argument may be made regarding privately owned real estate developments and mobile home parks. See, e.g., Private Abridgment, supra note 35 , at 168-71. The case for opening private property to public access is perhaps strongest when relatively helpless or immobile populations, such as the elderly or migrant laborers, are involved. See, e.g., State v. Shack, 58 N.J. 297, 307, 277 A.2d 369, 374 (1971) (finding, under state constitution, a right of access to migrant labor camps by government agency workers, charitable groups, visitors of workers' choice, and members of press). Often those seeking a right of access are activists or union organizers whose purpose is to prevent the exploitation of an isolated group by the property owner. See generally Note, Access to Migrant Labor Camps: Marsh v. Alabama Revisited, 55 CHr.-Kent L. REv. 285 (1979); Note, Listeners' Rights Providing a State Action Theory in the "Company Town" Analogues, 55 IND. L.J. 91 (1979). 
In addition, some universities are sufficiently self-contained that their students rarely leave the campus. ${ }^{171}$ Those students who are over the age of eighteen are also voters, and the state has a legitimate interest in insuring that they have easy access to voting information. ${ }^{172}$

Undoubtedly, the factors to be balanced against these interests are different in the case of a university from those involved in the case of a shopping center. Nevertheless, states have broad, wellestablished authority to regulate private property in the exercise of their police power, so long as they do not contravene any constitutional provision. ${ }^{173}$ The balance between the nonconstitutional interests of educational institutions and the nonconstitutional free speech rights of individual citizens is one that should be left to the individual states. Experimentation by the states in this relatively uncharted area may well lead to significantly greater rights of speech and assembly for their citizens, without any measureable harmful effect on their colleges and universities.

171 Among the on-campus facilities at Princeton are laundry rooms, a university newspaper, a "pub," several theaters, and an art museum. Jurisdictional Statement, supra note 17 , at $55 \mathrm{a}-57 \mathrm{a}$.

172 Approximately $87 \%$ of the Princeton student body is eligible to vote. Id. 54a. Schmid's leaflets concerned an upcoming Newark mayoralty election.

173 PruneYard Shopping Center v. Robins, 447 U.S. 74, 81 (1980). 